\title{
The Effect of Prenatal Interventions on Self-Efficacy in Women During Childbirth - A Systematic Review
}

\author{
Elise Timmermans $\mathbf{s}^{1,2 *}$, Olaf Timmermans $\mathbf{s}^{3,4}$, Eveline Mestdagh ${ }^{1,3}$ and Annick Bogaerts ${ }^{3,5}$ \\ ${ }^{1}$ Artesis-Plantijn University College Antwerp, Belgium \\ ${ }^{2}$ Reinier de Graaf ziekenhuis, Netherlands \\ ${ }^{3}$ Centre for Research and Innovation in Care, University Antwerp, Belgium \\ ${ }^{4}$ Professorship Healthy Region, HZ University of Applied Sciences, Netherlands \\ ${ }^{5}$ Department of Development \& Regeneration, KU Leuven, Belgium
}

Submission: September 25, 2019 , Published: September 30, 2019

*Corresponding author: Elise S. Timmermans, Artesis-Plantijn University College Antwerp, Belgium and Reinier de Graaf ziekenhuis, Netherland

\begin{abstract}
Introduction: Maternal Perinatal Self-Efficacy (MPSE) is a woman's believe in her ability to positively deal with childbirth. Low MPSE has been associated with fear of childbirth and negative childbirth outcomes. To enhance MPSE, educational interventions are set up to increase knowledge, empower women and teaching them useful coping strategies. However, until now no systematic evaluation of evidence on the effect of educational interventions on MPSE exists.
\end{abstract}

Objectives: The aim of this systematic review is to identify and appraise the existing evidence on the effectiveness of prenatal educational interventions on the MPSE of pregnant women.

Method: PubMed, Cochrane Library and Science direct were systematically searched by using keywords and MeSh terms such as prenatal education, childbirth and self-efficacy. Inclusion criteria were: English or Dutch language, published in the past 10 years, using a definition of selfefficacy in accordance with the definition of Bandura (1977), prenatal interventions performed by a qualified person and MPSE measured using the Childbirth Self-Efficacy Inventory (CBSEI). Selected articles were assessed on the quality and level of evidence by the means of the Critical Appraisal Skills Program checklist for randomized controlled trials (CASP).

Result: Six studies were included: four randomized controlled trials; one quasi-experimental study and one single-arm study. The total duration of the interventions varied from 180 minutes to 2.5 days. In three of the studies the research population consisted of nulliparous women, two studies included both nulliparous and multiparous women and in one study, the population consisted of women with an increased fear of childbirth. Both the content of the interventions and who the intervention executed varied per study. All studies reported a significant difference in MPSE as a result of the educational intervention. Both short-term individual programs and educational group sessions proved to be effective in increasing MPSE.

Conclusion: Prenatal educational interventions appear to make a significant positive difference in MPSE during childbirth, both in nulli- and multiparous women. It is clear that implementing some kind of a short-term educational program in prenatal care could increase MPSE.

Keywords: Maternal Perinatal; Besides physical; Obstetrical interventions; Mental resilience; Psychosocial factors; Depressive feelings; Childbirth; Epidural analgesia

Abbrevations: MPSE: Maternal Perinatal Self-Efficacy; CBSEI: Childbirth Self-Efficacy Inventory; CASP: Checklist for Randomized Controlled Trials

\section{Introduction}

Besides physical, also psychosocial characteristics influence the prevalence of obstetrical interventions e.g. caesarean deliveries, the choice for an epidural analgesia, satisfaction about childbirth and the presence of depressive feelings during the perinatal period [1]. However, research from prenatal education studies shows, that the aspect of mental health and the related factors are often not mentioned [2].

One of these factors is mental resilience, defined as the ability to cope with and manage challenges, stress and setbacks in life [3]. Mental resilience includes toughness, elasticity/resil- 
iency and the ability to recover [4]. Mental resilience is a multidimensional, variable and dynamic process and is the product of interaction between individual factors, such as optimism and environmental factors such as social support [5-8]. Mental resilience, according to Witteveen et al. [9], includes six psychosocial factors;
a) psychological flexibility
b) social support
c) active coping
d) active physical activity
e) (maternal perinatal) self-efficacy
f) optimism

The identification of psychosocial factors that positively influence perinatal outcomes (obstetric interventions, caesareans, epidural analgesia, satisfaction with childbirth and depressive feelings), is important for both healthcare providers and clients ensuring a coherent and balanced focus in midwife-led prenatal care and education [10]. One psychosocial factor that is promising in this is maternal self-efficacy (MPSE) [1]. Bandura [11] was the first to define self-efficacy. He defined this as someone's own assessment of how well one can carry out actions and interventions that are necessary for dealing with future situations. Two components can be extracted;

a) 'outcome expectancy', the conviction that his or her behaviour leads to a specific outcome and

b) 'efficacy expectations', the conviction in being able to show this specific behaviour [11].

In the past decades, the concept of self-efficacy has also been adopted in midwifery research. This hereby is referred to as MPSE defined as having self-confidence in the equity to be able to deal with childbirth [12]. Studies reported relations between MPSE and fear of childbirth. One of the first studies on MPSE showed that low maternal perinatal self-efficacy was associated with increased VBAC deliveries [13]. Christiaens [14] found a direct positive association between the degree of realization of expectations regarding childbirth, MPSE and the satisfactory feeling after childbirth. A strong sense of maternal self-efficacy was also linked to a less severe experience of pain during delivery [15]. Women with high fear of childbirth preferred an epidural anaesthetic while women with less fear sooner opted for a natural birth [16]. Women with high levels of anxiety also preferred giving birth by caesarean instead of choosing for a vaginal birth and were more likely to have obstetric interventions $[17,12]$. Finally, low maternal perinatal self-reliance was linked to more depressive symptoms, low knowledge about childbirth and the experience of discomfort during pregnancy. According to the theory of self-efficacy, there are four main ways of gaining self-efficacy:
a) personal experiences
b) vicarious experiences shared or seen by others
c) social conviction by encouragement from others and
d) emotional interpretations of physical states [11].

Based on research in other branches of health care, one can conclude that there is a possibility to enhance self-efficacy through educational interventions. Self-efficacy enhancing educational interventions primarily focus on increasing knowledge, empowering women and learning useful coping strategies [18], but lacks impact on self-confidence if any. Therefore, it seems essential to synthesise and critically appraise the reported evidence in published quantitative scientific studies on the influence of prenatal educational interventions on MPSE, and to bring this subject under consideration. The aim of this systematic review is to identify and appraise existing evidence on the effectiveness of prenatal educational interventions carried out by the midwife on the MPSE.

Figure 1: Visualization of the data search.

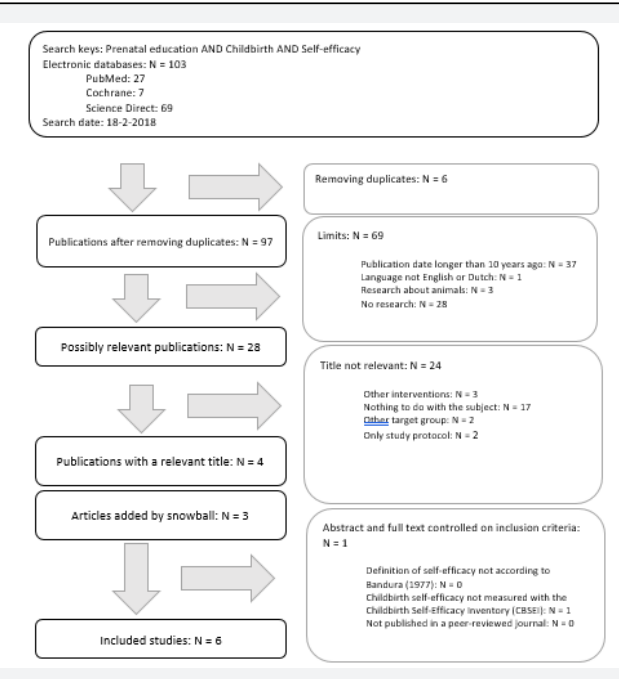




\section{Method}

PubMed, Cochrane Library and Science Direct have been searched for studies that met the inclusion criteria (see Figure 1) and by using keywords or MeSh terms such as: 'prenatal education', 'childbirth' and 'self-efficacy'. Inclusion criteria were: English or Dutch, published in the past 10 years, a definition of self-efficacy corresponding with the definition of Bandura [11], prenatal interventions which are performed by a qualified healthcare-worker, usage of the Childbirth Self-Efficacy Inventory (CBSEI) for measurement of perinatal self-efficacy, published in a peer-reviewed journal $(n=103)$. Duplicates were removed from the results $(n=6)$. After screening for inclusion criteria: self-efficacy according to Bandura's definition [11], use of the Childbirth self-efficacy inventory and published in a peer-reviewed journal, 28 possibly relevant publications were included. Of these, 24 articles were excluded because of non-educational interventions $(n=3)$, nothing to do with the subject $(n=17)$, another target group $(n=2)$ and article only describing the study protocol $(n=2)$. Finally four articles were included. An additional three publications were found using the snowball method. Full texts were checked and an additional article was excluded because of the use of another measurement instrument than the Childbirth Self-Efficacy Inventory, resulting in the final inclusion of six articles. Insert Figure 1 Visualization Of The Data Search About Here

Table 1: Critical assessment of included studies with Critical Appraisal Skills Program (CASP) checklist for Randomized controlled trials.

\begin{tabular}{|c|c|c|c|}
\hline & Author (year) & Journal & Quality Score* \\
\hline 1 & Toohill et al. [19] & BIRTH & $9 / 11$ \\
\hline 2 & Ip et al. [23] & Journal of Clinical Nursing & $10 / 11$ \\
\hline 3 & Sercekus et al. [21] & Midwifery & $9 / 11$ \\
\hline 4 & Byrne et al. [22] & Journal of Midwifery \& Women's & $7 / 11$ \\
\hline 5 & Duncan et al. [24] & BMC Pregnancy and Childbirth & $10 / 11$ \\
\hline 6 & İsbir et al. [20] & Applied Nursing Research & $8 / 11$ \\
\hline
\end{tabular}

The selected articles were assessed on quality and level of supplied evidence using the Critical Appraisal Skills Program (CASP) checklist for Randomized controlled trials. As Table 1 shows, the included studies generally achieve a high score on the CASP with the lowest score being $7 / 11(n=1)$. Because of the nature of these studies, none of them were double-blinded. In the study of Toohill et al. [19] there is no analysis of the base-line characteristics of the control group and the intervention group, making it unclear whether the results may be influenced by confounders. In the studies of Ibir et al. [20] and Sercekus et al. [21] there is no randomization, in the study by Isbir et al. [20] the self-efficacy score after the intervention is not compared with the self-efficacy of the control group. The research from Byrne et al. [22] is a single-arm trial, there is no control group, so reliability is lower.

Table 2: General description of the included studies.

\begin{tabular}{|c|c|c|c|c|c|c|c|c|}
\hline S.No & $\begin{array}{l}\text { Author } \\
\text { (year) }\end{array}$ & $\begin{array}{l}\text { Research } \\
\text { design }\end{array}$ & Intervention & Executive & Duration & $\begin{array}{c}\text { Measure } \\
\text { instrument }\end{array}$ & $\begin{array}{l}\text { Research popu- } \\
\text { lation }\end{array}$ & Outcomes \\
\hline 1 & $\begin{array}{c}\text { Toohill et al. } \\
\text { [19] }\end{array}$ & $\begin{array}{l}\text { Randomized } \\
\text { controlled trail }\end{array}$ & $\begin{array}{l}\text { BELIEF is a telephon- } \\
\text { ic psycho-education } \\
\text { counselling inter- } \\
\text { vention }\end{array}$ & Midwives & Unknown & $\begin{array}{l}\text { Childbirth } \\
\text { self-efficacy } \\
\text { inventory } \\
\text { (CBSEI) }\end{array}$ & $\begin{array}{c}198 \text { pregnant } \\
\text { women with high } \\
\text { levels of anxiety } \\
\text { Intervention group } \\
(\mathrm{n}=101) \\
\text { Control group (n } \\
=97)\end{array}$ & $\begin{array}{l}\text { Childbirth self-ef- } \\
\text { ficacy } \\
\text {-Fear } \\
\text {-Decisional conflict } \\
\text {-Depression }\end{array}$ \\
\hline 2 & Ip et al. [23] & $\begin{array}{l}\text { Randomized } \\
\text { controlled trail }\end{array}$ & $\begin{array}{l}\text { The self-efficacy } \\
\text { enhancing educa- } \\
\text { tional programme: } \\
\text { interactive educa- } \\
\text { tional sessions }\end{array}$ & A midwife & $\begin{array}{c}2 \text { sessions } \\
90 \text { minutes } \\
180 \text { minutes }\end{array}$ & $\begin{array}{l}\text { Childbirth } \\
\text { self-efficacy } \\
\text { inventory } \\
\text { (CBSEI) }\end{array}$ & $\begin{array}{l}133 \text { nulliparous } \\
\text { pregnant women } \\
\text { Intervention group } \\
(\mathrm{n}=60) \\
\text { Control group (n } \\
=73)\end{array}$ & $\begin{array}{l}\text { Childbirth self-ef- } \\
\text { ficacy } \\
\text {-Pain and anxiety } \\
\text { during labour } \\
\text {-Coping behaviours } \\
\text { during labour }\end{array}$ \\
\hline 3 & $\begin{array}{l}\text { Sercekus et al. } \\
{[21]}\end{array}$ & $\begin{array}{l}\text { Quasi-experi- } \\
\text { mental study }\end{array}$ & $\begin{array}{l}\text { Prenatal education in } \\
\text { groups of } 4-6 \text { couples }\end{array}$ & & $\begin{array}{c}8 \text { sessions } \\
120 \text { minutes } \\
960 \text { minutes }\end{array}$ & $\begin{array}{l}\text { Childbirth } \\
\text { self-efficacy } \\
\text { inventory } \\
\text { (CBSEI) }\end{array}$ & $\begin{array}{c}55 \text { pregnant } \\
\text { women } \\
\text { Intervention group } \\
(\mathrm{n}=28) \\
\text { Control group ( } \mathrm{n} \\
=27)\end{array}$ & $\begin{array}{l}\text { Childbirth self-ef- } \\
\text { ficacy } \\
\text {-Fear of childbirth } \\
\text {-Maternal and pa- } \\
\text { ternal attachment }\end{array}$ \\
\hline
\end{tabular}




\begin{tabular}{|c|c|c|c|c|c|c|c|c|}
\hline 4 & $\begin{array}{c}\text { Byrne et al. } \\
{[22]}\end{array}$ & Single arm trail & $\begin{array}{c}\text { Mindfulness-Based } \\
\text { Childbirth Education } \\
\text { Program }\end{array}$ & $\begin{array}{l}\text { A qualified } \\
\text { partus teacher, } \\
\text { a specialist } \\
\text { in prenatal } \\
\text { yoga and } \\
\text { mindfulness } \\
\text { meditation \& } \\
\text { registered yoga } \\
\text { and meditation } \\
\text { teacher }\end{array}$ & $\begin{array}{c}8 \text { sessions } \\
150 \text { minutes } \\
1200 \text { minutes }\end{array}$ & $\begin{array}{l}\text { Childbirth } \\
\text { self-efficacy } \\
\text { inventory } \\
\text { (CBSEI) }\end{array}$ & $\begin{array}{l}12 \text { pregnant } \\
\text { women }\end{array}$ & $\begin{array}{c}\text { Childbirth self-ef- } \\
\text { ficacy } \\
\text {-Depression } \\
\text {-Mindfulness } \\
\text {-Fear of birth } \\
\text {-Postnatal depres- } \\
\text { sion } \\
\text {-Anxiety } \\
\text {-Stress }\end{array}$ \\
\hline 5 & $\begin{array}{c}\text { Duncan et al. } \\
{[24]}\end{array}$ & $\begin{array}{l}\text { Randomized } \\
\text { controlled trail }\end{array}$ & $\begin{array}{l}\text { Mind in Labour } \\
\text { (MIL): Working with } \\
\text { pain in childbirth, an } \\
\text { educational partus } \\
\text { program that teaches } \\
\text { mindfulness skills }\end{array}$ & $\begin{array}{l}\text { A mindfulness } \\
\text { teacher, a nurse } \\
\text { and a midwife }\end{array}$ & 2.5 days & $\begin{array}{l}\text { Childbirth } \\
\text { self-efficacy } \\
\text { inventory } \\
\text { (CBSEI) }\end{array}$ & $\begin{array}{l}30 \text { nulliparous } \\
\text { pregnant women } \\
\text { Intervention group } \\
(\mathrm{n}=15) \\
\text { Control group (n } \\
=15)\end{array}$ & $\begin{array}{c}\text { Childbirth self-ef- } \\
\text { ficacy } \\
\text {-Maladaptive pain } \\
\text { appraisal } \\
\text {-Perceived pain in } \\
\text { labour } \\
\text {-Pain medication in } \\
\text { labour } \\
\text {-Birth satisfaction } \\
\text {-Mindfulness and } \\
\text { mindful body } \\
\text { awareness }\end{array}$ \\
\hline 6 & $\begin{array}{l}\text { Isbir et al. } \\
\text { [20] }\end{array}$ & $\begin{array}{l}\text { Randomized } \\
\text { controlled trail }\end{array}$ & $\begin{array}{l}\text { A structured prenatal } \\
\text { educational course }\end{array}$ & $\begin{array}{l}\text { Nurses an med- } \\
\text { ical doctors }\end{array}$ & $\begin{array}{l}4 \text { sessions } \\
240 \text { minutes } \\
960 \text { minutes }\end{array}$ & $\begin{array}{l}\text { Childbirth } \\
\text { self-efficacy } \\
\text { inventory } \\
\text { (CBSEI) }\end{array}$ & $\begin{array}{l}30 \text { nulliparous } \\
\text { pregnant women } \\
\text { Intervention group } \\
(\mathrm{n}=15) \\
\text { Control group ( } \\
=15)\end{array}$ & $\begin{array}{c}\text { Childbirth self-ef- } \\
\text { ficacy } \\
\text {-Fear of birth } \\
\text {-PTSD symptoms }\end{array}$ \\
\hline
\end{tabular}

\section{Result}

Six articles were included in this review. Table 2 Visualises the basic characteristics of the included studies. Four of the six studies were randomized controlled trials [12, 20, 23, 24]. The study from Sercekus et al. [21] was a quasi-experimental study and the study from Byrne et al. [22] was a single-arm trial. All studies were of sufficient quality and validity to be included in this review [25].

\section{Educational interventions and duration}

The included educational interventions varied in duration, effectuation and specific content. The intervention by Byrne et al. [22] included an 8-week program providing mindfulness-based education in 2.5-hour week-sessions. Duncan et al. [24] used 'Mind in Labour: working with Pain in Childbirth', an educational program concerning childbirth, teaching mindfulness skills during a 2.5-day workshop. Toohill et al. [19] used a telephonic psycho-education counselling intervention by midwives called BELIEF, from which the duration was not described. Both Sercekus et al. [21] and Isbir et al. [20] used a prenatal educational course that lasted 16 hours divided over several sessions. The self-efficacy enhancing educational program of Ip et al. [23], consisted of two 90-minute interactive educational sessions.

\section{Educator}

In three studies, midwives were involved in the educational intervention: The intervention by Ip et al. [23] was supervised by a registered midwife. In the study by Duncan et al. [24], the educational intervention was executed by a multidisciplinary team including a midwife. The psycho-education telephone-interven- tion in the study of Toohill et al [19]was executed by midwifes. Sercekus et al. [21] did not specify by whom the educational intervention was performed. The course described by course Byrne at al. [22], was led by a qualified specialist in prenatal yoga and mindfulness meditation, assisted by a registered yoga and meditation teacher. Isbir et al. [20] organized and supervised the course themselves.

\section{Childbirth self-efficacy inventory}

In all studies, the Childbirth self-efficacy inventory (CBSEI) was used to measure self-efficacy during active labour and the second stage of labour. This measuring instrument was developed by Lowe [26] and is based on the definition of self-efficacy of Bandura [11]. The CBSEI measures outcome expectancy and efficacy expectancy for dealing with the active labour and the second stage of labour. It is a self-reporting questionnaire consisting of 62 items with four subscales and two total scores. The four subscales are;

a) outcome expectancy active labour (Outcome AL, 15 items),

b) self-efficacy expectancy active labour (Efficacy-AL, 15 items),

c) outcome expectancy second stage (Outcome- SS, 16 items 31-46) and

d) self-efficacy expectancy second stage (Efficacy-SS, 16 items). A 4-point Likert scale was used to score the items, varying from 1 (not at all helpful or not at all certain) to 10 (very helpful or completely certain). 
Two outcomes are being calculated; the Outcome expectancy score (OE, range from 10-150) and Self-Efficacy expectancy score (EE, range 11-160). The higher the score, the higher the MPSE. These outcomes can be combined in the total self-efficacy expectancy score [27]. The measuring instrument was developed for usage during the third trimester of pregnancy when women start thinking about childbirth [28]. The CBSEI has been extensively studied, both the original version by Lowe (1993) and the translated versions by Tanglakmankhong et al. [28] and Gourounti et al. [27]. Using the Chinese version showed that women were not able to distinguish the differences between the active stage and the second stage of labour when filling in the questionnaire. As a result, Ip et al. [23] used a shortened version in their study in which the two repetitive self-efficacy subscales were omitted. All these studies concluded that the CBSEI is of sufficient validity for measuring self-efficacy during labour and delivery

\section{Research population}

In the studies by Ip et al. [23], Isbir et al. [20] and Duncan et al. [24], study population consisted of nulliparous women $(n=133$, $n=90, n=30$, respectively). Toohill et al. [19] pre-screened pregnant women with the use of the Wijma Delivery Expectancy/Experience Questionnaire Version A (W-DEQ A) and only anxious women regarding childbirth (defined as a score of $\geq 66$ on the W-DEQ A) were included ( $\mathrm{n}=198)$. In the studies by Byrne et al. [22] and Sercekus et al. [21] the study population consisted of pregnant women $(n=12, n=55$ respectively). In all studies with a control group ( $n=5)$, no significant differences were found in the sociodemographic baseline measurements and the pre-intervention measurement of maternal self-efficacy between the control group and the intervention group.

Table 3: Results Childbirth Self Efficacy Inquiry.

\begin{tabular}{|c|c|c|c|c|c|c|c|c|}
\hline \multirow{2}{*}{ Study } & \multicolumn{2}{|c|}{ Pretest CBSEI Mean(SD) Score } & \multicolumn{2}{|c|}{ Posttest CBSEI Mean (SD) Score } & \multicolumn{4}{|c|}{ Difference in Mean CBSEI Pre- En Posttest } \\
\hline & Control Group & $\begin{array}{l}\text { Intervention } \\
\text { Group }\end{array}$ & Control Group & $\begin{array}{l}\text { Intervention } \\
\text { Group }\end{array}$ & Control Group & $\begin{array}{l}\text { Intervention } \\
\text { Group }\end{array}$ & $\begin{array}{l}\text { Mean Change } \\
\text { Difference }\end{array}$ & P-Value \\
\hline $\begin{array}{l}\text { Toohill et al. } \\
\text { [19] }\end{array}$ & $385.9(102.9)$ & $368.5(122.5)$ & 405,6 & 429,6 & $19.70(92.61)$ & $61.10(87.45]$ & 41.4 & 0.002 \\
\hline \multicolumn{9}{|l|}{ Ip et al. [23] } \\
\hline \multirow{2}{*}{ EE } & $(20.35)$ & $107.28(23.36)$ & $(23.36)$ & $121.70(22.80)$ & & & & \\
\hline & 107.67 & & 104.93 & & & & & $<0.0001$ \\
\hline $\mathrm{OE}$ & $(19.69)$ & & $(19.79)$ & & & & & \\
\hline $\begin{array}{c}\text { Sercekus et al. } \\
{[21]}\end{array}$ & $222.7(37.4)$ & $219.3(37.7)$ & $224.1(37.8)$ & $257.6(44.9)$ & 1,4 & 38,3 & 36,9 & 0.002 \\
\hline Isbir et al. [20] & $229.8(51.1)$ & $224.1(54.5)$ & - & $297.9(17.8)$ & - & 73,8 & - & $<0.01$ \\
\hline
\end{tabular}

\section{Maternal self-efficacy}

Table 3 Baseline data of the included studies showed no significant difference in maternal self-efficacy (CBSEI score) between the intervention group and the control group prior to the intervention. Toohill et al. [19] reported a significant higher percentage of women in the intervention group scoring higher on the CBSEI $(n=74 / 97,76.3 \%)$ compared to the control group $(\mathrm{n}=55 / 91,60.4 \%)(\mathrm{p}=0.03)$, and also a significant difference in mean change difference between the intervention group and the control group (41.40, p=0.002). Ip et al. [23] found significant differences in the mean adjusted difference between the scores of the CBSEI Efficacy expectancy (EE) (95\% CI=14.2-30.3, $\mathrm{p}<0.0001)$ and Outcome expectancy (OE) $(95 \% \mathrm{CI}=10.2-24.6$, $\mathrm{p}<0.0001)$. A significant difference in the post-test mean CBSEI score of women in the intervention group (224.1 (37.8 SD)) com- pared with women in the control group (257.6 (44.9)) $(\mathrm{p}<0.01)$ was found by Sercekus et al. [21]. The study by Byrne et al. [22] reported a significant difference in the CBSEI scores before and after the intervention (171.69 (42.10 SD)) versus (224.54 (25.88 SD)), ( $p<0.001$ ). The study by Duncan et al. [24] showed that the mean CBSEI of the intervention group was significantly better compared to the control group (mean change difference $=64.4$, $80 \% \mathrm{CI}$ ). From the study by Isbir et al. [20], there is a significant difference in the mean scores for CBSEI after intervention $(229.8$ (51.2 SD) - 297.9 (17.8 SD), p <0.01). The mean change difference has been calculated for four studies [19, 21, 23, 24], See Table 3, There is a difference between mean change difference of the intervention group and the control group. For all studies, the difference in the pre-and post-test CBSEI score in the intervention group was calculated. An improvement in CBSEI-score 
was demonstrated in all studies, and scores differs from 35.43 to 78.20 .

\section{Discussion}

This systematic review aimed to identify and appraise existing evidence on the effectiveness of prenatal educational interventions carried out by the midwife on the MPSE and after a well-defined systematic search strategy, six studies were included. All studies reported a significant difference in MPSE as a result of prenatal educational interventions. From this review no clear link emerged with the actual set-up of the intervention. For example, both telephonic psycho-education counselling by midwives and prenatal education in groups increased MPSE. These findings suggest that both short-term individual programs and educational sessions in group are effective in increasing maternal self-efficacy. The involvement of midwives during the interventions contributed positively to the maternal self-efficacy. This aligns nicely to the findings of Sandall et al. [29] stating that midwife-led models reduce obstetric interventions and enhance women's satisfaction of care. The significant results of Duncan et al. [24] by use of the mindfulness intervention indicated an emphasis on a multidisciplinary cooperation.

The focus on the use of mindfulness during the interventional programs show promise, but due to the small study populations and the use of a single arm trial, we cannot say with certainty whether mindfulness training makes a difference in increasing maternal self-efficacy in comparison with prenatal education as such. Moreover, the geographic locations in which the included studies took place, may also impact the results. One was performed in China, two in Turkey, two in Australia and one in the United States. Possible social, cultural and regional influences might have influenced the effectiveness of the interventions in specified studied populations [30,31].

The search strategy has been performed precisely and the included studies were of sufficient quality and quantity. Given the differences in the studied populations e.g. regarding the parity and the degree of childbirth anxiety, it is advisable to be careful in generalizing the results of this review. The included studies were performed within a time span of seven years (2009-2017). Although this is a relatively short period of time, it might be possible that midwifery care or patients may have changed at this time. For example, in recent years information and communication throughout electronic devices and the internet have grown enormously.

Further research concerning which intervention is most efficient, and whether the intervention can best be integrated in prenatal care or be given as a separate course is recommended. Moreover, it is of importance to gain insight in the benefits of midwife-led care versus a multidisciplinary team or a combination of both. Finally, the studies included in this review only addressed short-term outcomes; it might be beneficial to study the long-term effects of MPSE programs, since there could be other benefits

\section{Conclusion}

Prenatal education appears to make a significant difference in maternal self-efficacy during childbirth. Implementing a short-term educational program in prenatal care can increase MPSE in both nulli- and multiparous women, and in women with a high fear of childbirth. This review did not clarify which intervention reaches the highest impact. Nor does this review gave clarity about the difference in effectiveness of interventions supervised by midwives versus the effectiveness of interventions supervised by another healthcare worker or in multidisciplinary teams. Although, research has shown the importance of continuity of care [29-31], studies analysing the effects of an educational intervention integrated in the standard prenatal care by the midwife on the MPSE are missing. Further research concerning which intervention is most efficient, whether it's best integrated in prenatal care or given as a separate additional course is recommended.

\section{References}

1. Tilden EL, Caughey AB, Lee CS, Emeis C (2016) The Effect of Childbirth Self-Efficacy on Perinatal Outcomes. J Obstet Gynecol Neonatal Nurs 45(4): 465-480.

2. Hildingsson I (2012) Mental training during pregnancy. Feelings and experiences during pregnancy and birth and parental stress 1 year after birth-a pilot study. Sex Reprod Healthc 3(1): 31-36.

3. Waugh CE, Koster EH (2014) A resilience framework for promoting stable remission from depression. Clin Psychol Rev 41: 49-60.

4. Leppin AL, Bora PR, Tilburt JC, Gionfriddo MR, Zeballos-Palacios C, et al. (2014) The Efficacy of Resiliency Training Programs: A Systematic Review and Meta-Analysis of Randomized Trials. Plos One 9(10): e111420.

5. Southwick SM, Charney DS (2012) The Science of Resilience: Implications for the Prevention and Treatment of Depression. Science 338(6103): 79-82.

6. Kalisch R, Müller MB, Tüscher O (2015) A conceptual framework for the neurobiological study of resilience. Behav Brain Sci 38: e92.

7. Rutten BPF, Hammels C, Geschwind N, Menne-Lothmann C, Pishva E, et al. (2013) Resilience in mental health: linking psychological and neurobiological perspectives. Acta Psychiatrica Scandinavica 128(1): $3-20$.

8. Johnston MC, Porteous T, Crilly MA, Burton CD, Elliott A, et al. (2015) Physical Disease and Resilient Outcomes: A Systematic Review of Resilience Definitions and Study Methods. Psychosomatics 56(2): 168180.

9. Witteveen A, Walker A, Henrichs J (2017) Knowledge synthesis mental resilience and antepartum depression (Kennis synthese mentale weerbaarheid en antepartum depressie). Netherlands (in Dutch).

10. Olza I, Leahy-Warren P, Benyamini Y, Kazmierczak M, Karlsdottir SI, et al. (2018) Women's psychological experiences of physiological childbirth: a meta-synthesis. BMJ Open 8(10): e020347.

11. Bandura A (1977) Self-efficacy: Toward a unifying theory of behavioral change. Psychol Rev 84(2): 191-215.

12. Schwartz L, Toohill J, Creedy DK, Baird K, Gamble J, et al. (2015) Factors associated with childbirth self-efficacy in Australian childbearing women. BMC Pregnancy Childbirth 15(1): 29.

13. Dilks FM, Beal JA (1997) Role of Self-Efficacy in Birth Choice. J Perinat Neonatal Nurs 11(1): 1-9. 
14. Christiaens W, Bracke P (2007) Assessment of social psychological determinants of satisfaction with childbirth in a cross-national perspective. BMC Pregnancy Childbirth 7(1): 26.

15. Berentson-Shaw J, Scott KM, Jose PE (2009) Do self-efficacy beliefs predict the primiparous labour and birth experience? A longitudinal study. Journal of Reproductive and Infant Psychology 27(4): 357-373.

16. Lowe NK (2009) Self-efficacy for labor and childbirth fears in nulliparous pregnant women. J Psychosom Obstet Gynaecol 21(4): 219-224.

17. Salomonsson B, Gullberg MT, Alehagen S, Wijma K (2013) Self-efficacy beliefs and fear of childbirth in nulliparous women. J Psychosom Obstet Gynaecol 34(3): 116-121.

18. Lev EL, Owen SV (2000) Counselling women with breast cancer using principles developed by Albert Bandura. Perspect Psychiatr Care 36(4): 131-138.

19. Toohill J, Gamble FJ, Creedy DK, Buist A, Turkstra E, et al. (2014) A Randomized Controlled Trial of a Psycho-Education Intervention by Midwives in Reducing Childbirth Fear in Pregnant Women. Birth 41(4) 384-394.

20. Gökçeİsbir G, İnci F, Önal H, Dıkmen YP (2016) The effects of antenatal education on fear of childbirth, maternal self-efficacy and posttraumatic stress disorder (PTSD) symptoms following childbirth: an experimental study. Appl Nurs Res 32: 227-232.

21. Serçekuş P, Başkale H (2016) Effects of antenatal education on fear of childbirth, maternal self-efficacy and parental attachment. Midwifery 34: 166-172.

22. Byrne J, Hauck Y, Fisher C, Bayes S, Schutze R, et al. (2014) Effectiveness of a Mindfulness-Based Childbirth Education Pilot Study on Maternal Self-Efficacy and Fear of Childbirth. J Midwifery Womens Health 59(2): 192-197.
23. Ip WY, Tang CSK, Goggins WB (2009) An educational intervention to improve women's ability to cope with childbirth. J Clin Nurs 18(15): 2125-2135.

24. Duncan LG, Cohn MA, Chao MT, Cook JG, Riccobono J, et al. (2017) Benefits of preparing for childbirth with mindfulness training: a randomized controlled trial with active comparison. BCM Pregnancy and Childbirth 17: 140-151.

25. Critical Appraisal Skills Programme (2017) CASP Randomised Controlled Trail.

26. Lowe NK (1993) Maternal confidence for labor: Development of the childbirth self-efficacy inventory. Res Nurs Health 16(2): 141-149.

27. Gourounti K, Kouklaki E, Lykeridou K (2015) Childbirth efficacy: Validating the childbirth self-efficacy inventory in a Greek sample of pregnant women. Midwifery 31(7): 742-749.

28. Tanglakmankhong K, Perrin NA, Lowe NK (2010) Childbirth Self-Efficacy Inventory and Childbirth Attitudes Questionnaire: psychometric properties of Thai language versions. J Adv Nurs 67(1): 193-203.

29. Sandall J, Soltani H, Gates S, Shennan A, Devane D, et al. (2016) Midwifeled continuity models versus other models of care for childbearing women. Cochrane Database Syst Rev 4: CD004667.

30. Kildea S, Simcock G, Liu A, Elgbeili G, Laplante DP, et al. (2017) Continuity of midwifery carer moderates the effects of prenatal maternal stress on postnatal maternal wellbeing: the Queensland flood study. Archives of women's mental health 21(2): 203-214.

31. Brixval CS, Axelsen SF, Thygesen LC, Due P, Koushede V, et al. (2016) Antenatal education in small classes may increase childbirth selfefficacy: Results from a Danish randomised trial. Sex Reprod Healthc 10: $32-34$. 
- Quality Editorial service

- Swift Peer Review

- Reprints availability

- E-prints Service

- Manuscript Podcast for convenient understanding

- Global attainment for your research

- Manuscript accessibility in different formats

( Pdf, E-pub, Full Tsext, Audio)

- Unceasing customer service

Track the below URL for one-step submission https://juniperpublishers.com/online-submission.php 